\title{
JUDUL “LATAH”, JUDUL WARISAN LAPORAN TUGAS AKHIR PENCIPTAAN KRIYA 2012-2017
}

\author{
Retno Purwandari ${ }^{1}$ (Jurusan Seni Kriya, Fakultas Seni Rupa, Institut Seni Indonesia Yogyakarta)
}

\begin{abstract}
This paper is the result of the research that examines the titles of the final project reports on the creation of the Kriya major in the art faculty of the Indonesian Art Institute in Yogyakarta 2012-2017. This research was triggered because the titles of the final project students seemed monotonous and not challenging, there was no suitability of the purpose conveyed in the visual language of artwork created with the lingual language of the final assignment report title. Data collection is done directly in the library majoring of Kriya. The data found is linguistically classified, then analyzed from the language structure and highlighted aspects. The result found are in accordance with the hypothesis that the titles of the final assignments from 2012-2017 are very monotonous because they are dominated by two forms of title styles with only one aspect of prominence, namely the source of creation. This is very unfortunate, because students cannot take the opportunity to express their art expressively and scientifically through the final project title. Therefore, through the results of the study students are expected to be more able to higlight other aspects that are in accordance with what is emphasized in his artwork into the final project title.
\end{abstract}

Keywords: "Latah" title, the title of final report on the creation of Kriya

\begin{abstract}
ABSTRAK
Tulisan ini merupakan hasil penelitian yang menelaah judul-judul Tugas Akhir (TA) Laporan Penciptaan di Jurusan Kriya, Fakultas Seni Rupa, ISI Yogyakarta tahun 2012-2017. Penelitian ini tercetus dikarenakan judul-judul TA mahasiswa terkesan monoton dan tidak menantang, tidak ada kesesuaian maksud dari yang disampaikan pada bahasa visual dari karya seni yang diciptakan dengan bahasa lingual judul laporan TA-nya. Pengumpulan data dilakukan secara langsung di perpustakaan Jurusan Kriya. Data yang ditemukan diklasifikasi secara kebahasaan, kemudian dianalisis dari struktur bahasa dan aspek yang ditonjolkan. Hasil yang ditemukan sesuai dengan hipotesis awal bahwa judul-judul TA dari tahun 2012-2017 sangat monoton karena didominasi oleh dua bentuk gaya judul dengan satu aspek penonjolan saja, yakni aspek sumber penciptaan. Hal ini sangat disayangkan karena mahasiswa tidak bisa mengambil kesempatan untuk membahasakan karya seninya secara ekspresif dan ilmiah melalui judul TA. Oleh karena itu, melalui hasil penelitian ini diharapkan nantinya mahasiswa lebih bisa menonjolkan aspek-aspek lain yang sesuai dengan apa yang ditekankan di karya seninya ke dalam judul TA.
\end{abstract}

Kata Kunci: Judul “Latah”, judul TA Laporan Penciptaan Kriya 


\section{PENDAHULUAN}

Penulisan merupakan salah satu bentuk tanggung jawab akademis yang harus dilakukan oleh semua insan akademis termasuk mahasiswa. Tidak memedulikan dari jurusan, program studi, atau spesialisasi apapun, semua mahasiswa harus melakukan proses kreatif bermediakan bahasa tulis ini. Hasil-hasil penulisan akademis yang dipraktikkan oleh mahasiswa inilah yang disebut dengan tulisan akademik atau karya tulis akademik atau karya tulis ilmiah. Menurut Dewojati (2012: 49), karya tulis disebut ilmiah jika mengemukakan gagasan keilmuan yang didukung oleh data, rujukan teori dan pendapat para ahli, analisis, dan metodologi tertentu.

Tidak terkecuali oleh mahasiswa seni yang lebih senang berkutat dengan pengerjaan karya-karya seni, mereka tidak bisa lepas dari tanggung jawabnya sebagai seorang akademis untuk mempertanggungjawabkan semua pekerjaan seninya dalam bentuk karya tulis ilmiah. Dari berbagai tulisan akademis, tugas akhir (skripsi) merupakan salah satu tulisan yang paling banyak mendapat perhatian, baik oleh mahasiswa itu sendiri maupun dosen, karena skripsi untuk saat ini masih dipercaya sebagai salah satu masterpiece bagi mahasiswa tingkat akhir yang akan mendapatkan gelar kesarjanaannya.

Tugas akhir atau yang sering dikenal dengan sebutan TA (Tugas Akhir) merupakan penyebutan yang bisa disepadankan dengan yang kita kenal dengan skripsi. Istilah TA ini digunakan untuk menyebutkan skripsi dari para mahasiswa Fakultas Seni Rupa, Institut Seni Indonesia (ISI) Yogyakarta. Tugas Akhir (untuk selanjutnya kita sebut dengan TA) merupakan tugas karya tulis ilmiah untuk pengkajian atau penciptaan/perancangan karya seni rupa yang harus diselesaikan oleh mahasiswa sebagai salah satu syarat guna mengakhiri studinya pada jenjang strata satu (S1). TA Pengkajian adalah karya tulis yang dihasilkan dari penelitian yang menerapkan pola pikir dan metode ilmiah sesuai dengan bidang studi/keahlian yang dipelajari, sedangkan TA Penciptaan/Perancangan adalah karya tulis yang dihasilkan dari kegiatan penciptaan yang memuat gagasan, wujud, dan teknik berdasarkan kaidah-kaidah estetika sesuai dengan bidang studi/keahlian yang dipelajari, serta penjelasan sistematik dalam bentuk tulisan (Pedoman Pembimbingan Tugas Akhir, 2016: 1).

Salah satu hal yang menarik perhatian berkaitan dengan TA mahasiswa kriya ini ialah judul-judul TA terutama TA Penciptaan. Berdasarkan pengamatan selama ini, pemberian judul TA Penciptaan mahasiswa kriya terkesan monoton. Penulis mengistilahkan mahasiswa menggunakan gaya latah dalam penyusunan judul TA Penciptaan. Mereka seolah-olah hanya sekedar melestarikan gaya bahasa judul-judul TA yang sudah ada sebelumnya, seperti mendapat warisan dari mahasiswa-mahasiswa terdahulu. Sebagai contoh, melihat daftar TA terbaru mahasiswa kriya 2017, dari 33 judul yang terdaftar, 15 judul di antaranya menganut gaya latah dalam penyusunan judulnya. Gaya latah yang dimaksud ialah gaya dengan susunan judul yang bisa dirumuskan: " $X$ sebagai Sumber Ide Penciptaan Karya Y". Dari hasil pengamatan sekilas ini, memberi motivasi penulis untuk lebih gencar lagi memperhatikan seluk-beluk TA, khususnya dalam pemberian judul TA Penciptaan.

Dari penelitian ini ditemukan gaya penyusunan judul-judul TA yang selama ini "diagung-agungkan". Benar adanya bahwa susunan judul TA " $X$ sebagai Sumber Ide Penciptaan Karya $Y$ " merupakan gaya latah yang masih lestari sampai saat ini. Dengan menganut gaya latah tersebut, mahasiswa 
terkesan tidak memiliki tantangan untuk menonjolkan karya seni ciptaannya, ada apakah di balik karya seni yang mereka buat yang bisa mereka komunikasikan dan pamerkan kepada orang lain, tidak hanya sekedar menunjukkan sumber ide penciptaannya. Untuk itu, melalui penelitian ini pula diharapkan mampu memberikan pemahaman baru bahwa ada banyak hal yang bisa ditonjolkan yang bisa dikomunikasikan dari karya seni hasil TA melalui judul-judul TA yang kreatif dan menarik yang tidak hanya sekedar menunjukkan sumber penciptaannya.

\section{Tinjauan Pustaka dan Landasan Teori}

Penelitian yang berkenaan dengan TA mahasiswa terutama yang berkaitan dengan gaya kebahasaannya masih jarang dilakukan. Penelitian ini lebih banyak melakukan observasi langsung bersinggungan dengan data-data yang ada di lapangan, yakni TA Penciptaan mahasiswa kriya yang ada di perpustakaan Jurusan Kriya, Fakultas Seni Rupa, ISI Yogyakarta.

\section{a. Bagian Utama Tugas Akhir (TA) Karya Seni}

Untuk mengetahui aspek-aspek penting penciptaan karya seni yang bisa ditonjolkan di dalam judul TA, peneliti menggunakan buku "Pedoman Pembimbingan Tugas Akhir 2016" untuk mengetahui poinpoin penting penciptaan karya seni, serta untuk mengetahui proses pengerjaan karya secara sistematis. Bagian utama naskah TA karya seni memuat: pendahuluan, konsep penciptaan, proses penciptaan, foto karya, dan tinjauan karya. Masing-masing muatan yang terdapat dalam bagian utama naskah TA karya seni ini menjabarkan hal-hal penting dari keseluruhan proses pengerjaan TA, mulai dari didapatkannya ide sampai dideskripsikannya karya-karya seni TA yang sudah terwujud. Semua hal yang dipaparkan pada bagian utama naskah TA tersebut mengandung aspek-aspek penting yang bisa ditelaah oleh mahasiswa, aspek manakah yang akan ditonjolkan. Hal ini bisa menjadi bahan penyusun judul TA penciptaan karya seni.

\section{b. Judul Karya Ilmiah}

Pengetahuan tentang judul tulisan terutama judul untuk tulisan ilmiah sangat penting untuk diketahui sebagai acuan dalam keterampilan menyusun sebuah judul. Sisi kebahasaan terutama tata tulis juga penting untuk diperhatikan sebagai nilai tambah daya tarik dari sebuah tulisan (Dewojati, 2012: 53). Djuroto (2009: 8-10) mengatakan bahwa memilih judul memerlukan perhatian khusus. Memilih judul memerlukan pemikiran, pertimbangan, dan penyesuaian secara khusus. Menurutnya, judul yang baik sebaiknya memenuhi beberapa kriteria, yaitu: atraktif dan baru, tidak panjang, serta memiliki relevansi. Gaya bahasa sebuah judul sebisa mungkin menggambarkan inti dari sebuah tulisan, sehingga bisa dikatakan penulis berhasil mengomunikasikan maksud tulisan kepada pembaca. Indriati mengatakan bahwa judul sebaiknya jangan terlalu umum. Semestinya judul dibuat lebih spesifik (2003: 14-15). Semakin spesifik judul yang dibuat artinya sudah ada pembatasan pembahasan permasalahan.

\section{c. Sintaksis}

Menurut Ramlan (1996: 21), sintaksis adalah cabang dari ilmu bahasa yang membicarakan seluk-beluk wacana, kalimat, klausa, dan frase. Kajian sintaksis dimaksudkan untuk mengetahui struktur satuan-satuan sintaksis, yaitu strukturstruktur kalimat, klausa, frase, dan kata (Chaer, 2007: 59). Teori sintaksis ini digunakan sebagai pisau bedah untuk menganalisis struktur kebahasaan dari judul-judul TA sebagai objek kajiannya, mengingat bahwa salah satu syarat judul ialah tidak boleh 
berupa kalimat tetapi harus berupa kata atau frase.

\section{METODE PENELITIAN}

Judul-judul karya tulis ilmiah termasuk TA terbentuk menggunakan unsurunsur satuan kebahasaan, yakni kata dan frase. Oleh karena itu, penelitian ini tidak bisa mengabaikan metode penelitian bahasa, yakni menyangkut cara kerja dalam rangka memerikan bahasa. Menurut Sudaryanto, pemerian bahasa yang dimaksud tidak hanya terbatas pada memaparkan apa dan bagaimana bahasa, tetapi juga memaparkan mengapa dan bahkan juga kapannya bahasa (Kesuma, 2007: 4). Hal yang dimaksud di sini, penelitian ini tidak hanya sekedar mencari seperti apa pembentukan judul TA dilihat dari bahasa yang dipakainya, namun juga harus melihat alasan pembentukannya, yakni mengapanya, dengan melihat aspek-aspek yang melingkupi proses penciptaan karya seni TA sebagai objek yang dibahasakan dalam judul TA.

\section{a. Metode Pengumpulan Data}

Pengumpulan data dalam penelitian ini dilakukan dengan menggunakan dua cara, yakni dengan studi pustaka dan studi lapangan. Studi pustaka dimanfaatkan dalam merunut judul-judul TA dari tahun 2012-2017, serta melihat aspek-aspek utama yang terkandung dalam naskah TA tersebut. Oleh karena itu, data-data diambil dari naskahnaskah TA dari tahun 2012-2015. Pencarian data ini dilakukan dengan menggunakan teknik dokumentasi, yakni teknik catat, teknik kopi (penggandaan), dan teknik foto.

Metode pengumpulan data yang kedua ialah melalui studi lapangan. Studi lapangan dilakukan di perpustakaan Jurusan Kriya, Fakultas Seni Rupa, ISI Yogyakarta dan kantor administrasi Jurusan Kriya, Fakultas Seni Rupa, ISI Yogyakarta. Pada pencariannya, peneliti menggunakan teknik kopi arsip dari berkas/dokumen jurusan.

\section{b. Metode Analisis Data}

Data yang didapatkan, yakni juduljudul TA dianalisis berdasarkan bentuk judul dilihat dari satuan kebahasaan, susunan kebahasaannya, dan aspek yang ditonjolkan. Pada tahap awal, data diklasifikasi menggunakan teori sintaksis. Penelitian sintaksis bertujuan memerikan kaidah-kaidah pembentukan frase dan kalimat, mengatur bergabungnya kata dengan kelompok kata dalam frase atau kalimat (Subroto, 2007: 57). Dalam hal ini, teori sintaksis ini digunakan untuk mendeskripsikan gaya bahasa juduljudul TA dilihat dari satuan kebahasaannya.

Dari hasil analisis dibuatlah klasifikasi judul-judul TA. Menurut Sudaryanto melalui Subroto (2007: 59-60), metode padan disebut juga dengan metode identitas, dipakai untuk menentukan identitas satuan lingual tertentu dengan menggunakan alat penentu yang berada di luar bahasa yang bersangkutan. Metode ini dimanfaatkan untuk mengidentifikasi identitas judul-judul TA dengan alat penentu, yakni aspek-aspek bahasa tulis yang ditonjolkan dalam wacana TA. Hal inilah yang dimaksudkan Sudaryanto memaparkan "mengapa" dalam Kesuma (2007: 4), kaitannya hubungan aspek-aspek utama TA dalam pembentukan judul-judul TA. Hasil akhir akan dibuat alternatif penggayaan judul TA.

\section{c. Metode Penyajian Analisis Data}

Penyajian analisis data dilakukan secara kualitatif. Hasil analisis dan simpulannya dipaparkan secara deskriptif. Pemaparan disajikan secara lengkap dengan bahasa terstruktur, yang jika diperlukan akan dilengkapi dengan skema dan tabel. 


\section{HASIL PENELITIAN}

Penelitian ini telah melakukan beberapa kegiatan, di antaranya: pengumpulan data, pengklasifikasian data, dan penganalisisan data.

\section{a. Pengumpulan Data dan Hasilnya}

Tabel pemerolehan data judul TA Penciptaan dipaparkan di bawah ini:

Tabel 1. Judul-Judul TA Penciptaan Tahun 2012-2017 Jurusan Kriya, ISI Yogyakarta

\begin{tabular}{|c|c|c|c|}
\hline Tahun Ajaran & Semester Gasal & Semester Genap & Total \\
\hline 2012-2013 & 5 Judul & 4 Judul & 9 judul \\
\hline $2013-2014$ & 15 Judul & 6 Judul & 21 Judul \\
\hline $2014 \cdot 2015$ & 15 Judul & 21 Judul & 36 Judul \\
\hline $2015-2016$ & 19 Judul & 17 jueul & 36 Judul \\
\hline $2016-2017$ & 22 Judul & 36 Judul & 58 Judul \\
\hline Total & & & Judul \\
\hline
\end{tabular}

Dari tabel di atas tergambar bahwa dari tahun 2012-2017 terjadi peningkatan jumlah mahasiswa yang mengajukan ujian TA tiap semesternya. Hal ini menunjukkan kemajuan terhadap proses pembelajaran di Jurusan Kriya, ISI Yogyakarta.

\section{b. Penganalisisan Data}

\section{Mengidentifikasi Judul Berdasarkan Satuan Kebahasaan}

Data yang telah diperoleh, berupa judul-judul TA kemudian dianalisis berdasarkan satuan kebahasaan. Kriteria judul yang baik dilihat dari segi kebahasaan, salah satunya tidak boleh berupa kalimat, tetapi berupa kata atau frase. Dari keseluruhan judul yang telah didapatkan, 160 judul, hanya ada 5 (lima) judul yang tidak memenuhi, karena dilihat dari satuan kebahasaan termasuk dalam wujud kalimat. Hal ini merupakan hasil cukup bagus dilihat dari satuan kebahasaan, karena hanya ada 3,12\% yang tidak memenuhi syarat sebagai judul yang baik.
Salah satu wujud kebahasaan bisa disebut kalimat jika dianalisis dari segi fungsinya minimal memiliki fungsi $S$ (Subjek) dan P (Predikat), sedangkan wujud kata atau frase tidak memiliki keduanya. Oleh karena itu, jika dalam suatu judul ditemukan unsur $\mathrm{S}$ dan $\mathrm{P}$, bisa dipastikan judul tersebut tidak memenuhi syarat sebagai judul yang baik, karena berupa kalimat.

Judul yang baik harus berupa kata atau frase. Menurut Ramlan (1996: 152), frase merupakan satuan gramatik atau kebahasaan yang terdiri atas dua kata atau lebih yang tidak melebihi batas fungsi unsur klausa, artinya frase selalu terdapat dalam satu fungsi unsur klausa, yakni S (Subjek), P (Predikat), O (Objek), Pel (Pelengkap), atau K (Keterangan). Frase terdiri atas unsur inti dan atau atribut; atau ada yang mengistilahkan unsur $D$ (Diterangkan/inti) dan atau $M$ (Menerangkan/atribut). Kridalaksana menyebutkan bahwa frase memiliki unsurunsur yang berhubungan secara fungsional, yaitu induk dan pewatas, atau perangkai dan sumbu (2002: 32).

Kelima judul yang tidak memenuhi syarat sebagai judul yang baik karena bentuknya berupa kalimat, yakni: (1) "Imajinasi Manusia Setengah Binatang Terinspirasi dari Perilaku Manusia dan Binatang", (2) "Bunga Anggrek Menjadi Inspirasi Karya Bordir", (3) "Kupu-Kupu Menjadi Sumber Inspirasi Busana Pesta Malam", (4) "Dampak Positif dan Negatif Game Online Divisualisasikan dalam Karya Kriya Logam", dan (5) "Stilisasi Bentuk Gitar Menjadi Ide Penciptaan Kap Lampu Logam". Berikut disertakan satu contoh analisis judul yang tidak memenuhi syarat kebahasaan.

"Bunga Anggrek Menjadi Inspirasi Karya Bordir"

Judul di atas berupa kalimat dengan pola S-PPel. 
Bunga Anggrek/ menjadi/ inspirasi karya bordir.

\section{$S \quad P$ Pelengkap}

Fungsi S diduduki frase bunga Anggrek, fungsi P diduduki kata menjadi, dan fungsi Pel diduduki frase inspirasi karya bordir.

\section{Mengidentifikasi dan Mengklasifikasi Gaya Penyusunan Judul}

Pada tahap ini dilakukan analisis dengan melihat gaya penyusunan judul dari 155 judul yang berupa frase. Untuk mempermudah penyajian rumusan gaya susunan judul TA Penciptaan Jurusan Kriya, di bawah ini akan dipaparkan beberapa lambang dan maknanya dalam tabel yang dipakai dalam perumusan gaya judul TA.
Tabel 2. Daftar Singkatan dan Lambang

\begin{tabular}{|c|c|c|}
\hline No. & $\begin{array}{l}\text { Tanda/ } \\
\text { Lambang/ } \\
\text { Singkatan }\end{array}$ & Makna \\
\hline 1. & $\mathrm{D}$ & dalam \\
\hline 2. & $\mathrm{M}$ & melalui \\
\hline 3. & $P$ & pada \\
\hline 4. & $\mathrm{~S}$ & sebagai \\
\hline 5. & $\mathrm{U}$ & untuk \\
\hline 6. & W & $\begin{array}{l}\text { merujuk pada pengertian } \\
\text { 'teknik' }\end{array}$ \\
\hline 7. & $\mathrm{X}$ & $\begin{array}{l}\text { merujuk pada pengertian } \\
\text { 'sesuatu yang menjadi } \\
\text { sumber/ide penciptaan' }\end{array}$ \\
\hline 8. & $\mathrm{Y}$ & $\begin{array}{l}\text { merujuk pada pengertian } \\
\text { 'suatu karya yang } \\
\text { diciptakan' }\end{array}$ \\
\hline 9. & Z & $\begin{array}{l}\text { merujuk pada pengertian } \\
\text { 'fungsi karya' }\end{array}$ \\
\hline 10. & $Y g$ & yang \\
\hline 11. & $\ldots$ & rangkaian kata \\
\hline 12. & + & dengan \\
\hline 13. & / & atau \\
\hline 14. & : & $\begin{array}{l}\text { merujuk pada tanda: } \\
\text { dalam ejaan }\end{array}$ \\
\hline 15. & () & $\begin{array}{l}\text { merujuk pada tanda () } \\
\text { dalam ejaan }\end{array}$ \\
\hline 16. & ' & $\begin{array}{l}\text { merujuk pada pengertian } \\
\text { 'turunan', misal: } X^{\prime} \\
\text { merujuk pada pengertian } \\
\text { turunan dari } X\end{array}$ \\
\hline
\end{tabular}

Dari hasil analisis data-data yang berupa judul TA Penciptaan berjumlah 155 judul, ditemukan 15 rumus gaya penyusunan judul. Tabel di bawah ini mendeskripsikan 15 temuan rumus gaya penyusunan judul tersebut. 
Tabel 3. Rumus Gaya Penyusunan Judul TA Penciptaan Mahasiswa Kriya, ISI Yogyakarta

\begin{tabular}{|c|c|c|c|c|c|c|c|c|c|c|c|c|c|c|c|}
\hline Tahus & $x \in S_{-}$ & $x \_d / D_{\perp} Y$ & $x$ & $x \_r$ & $x$ Xye_y & $x, m_{2} y$ & $X_{-} d / p_{-} Y_{-} s / u_{Z} z$ & $X \leq Y_{-} u / d, Z$ & $Y\left(Y^{\prime}\right)$ & Y.s. $x$ & $y_{-} d_{-} x$ & $v: x$ & $y_{2} z$ & $Y \cdot W$ & $W_{-} Y X X_{-} Y$ \\
\hline $\begin{array}{l}2012 \\
2013\end{array}$ & 2 & 4 & & & & & & & & & & & 1 & 1 & \\
\hline $\begin{array}{l}2013 \\
2014\end{array}$ & 6 & 10 & 1 & 1 & & & & & & & & & & & 2 \\
\hline $\begin{array}{l}2014- \\
2015\end{array}$ & 16 & 14 & 1 & & 1 & 1 & 1 & & & & 1 & & & & \\
\hline $\begin{array}{l}2015 \\
2016\end{array}$ & at & 21 & & & & & & 1 & 1 & 1 & & 1 & & & \\
\hline $\begin{array}{l}2016- \\
2017\end{array}$ & 20 & 34 & 1 & & & & 1 & 1 & & & & & & & \\
\hline Total & 55 & 83 & 3 & 1 & 1 & 1 & 2 & 2 & 1 & 1 & 1 & 1 & 1 & 1 & 1 \\
\hline
\end{tabular}

\section{RUMUS GAYA PENYUSUNAN JUDUL TA PENCIPTAAN MAHASISWA KRIYA, ISI YOGYAKARTA}

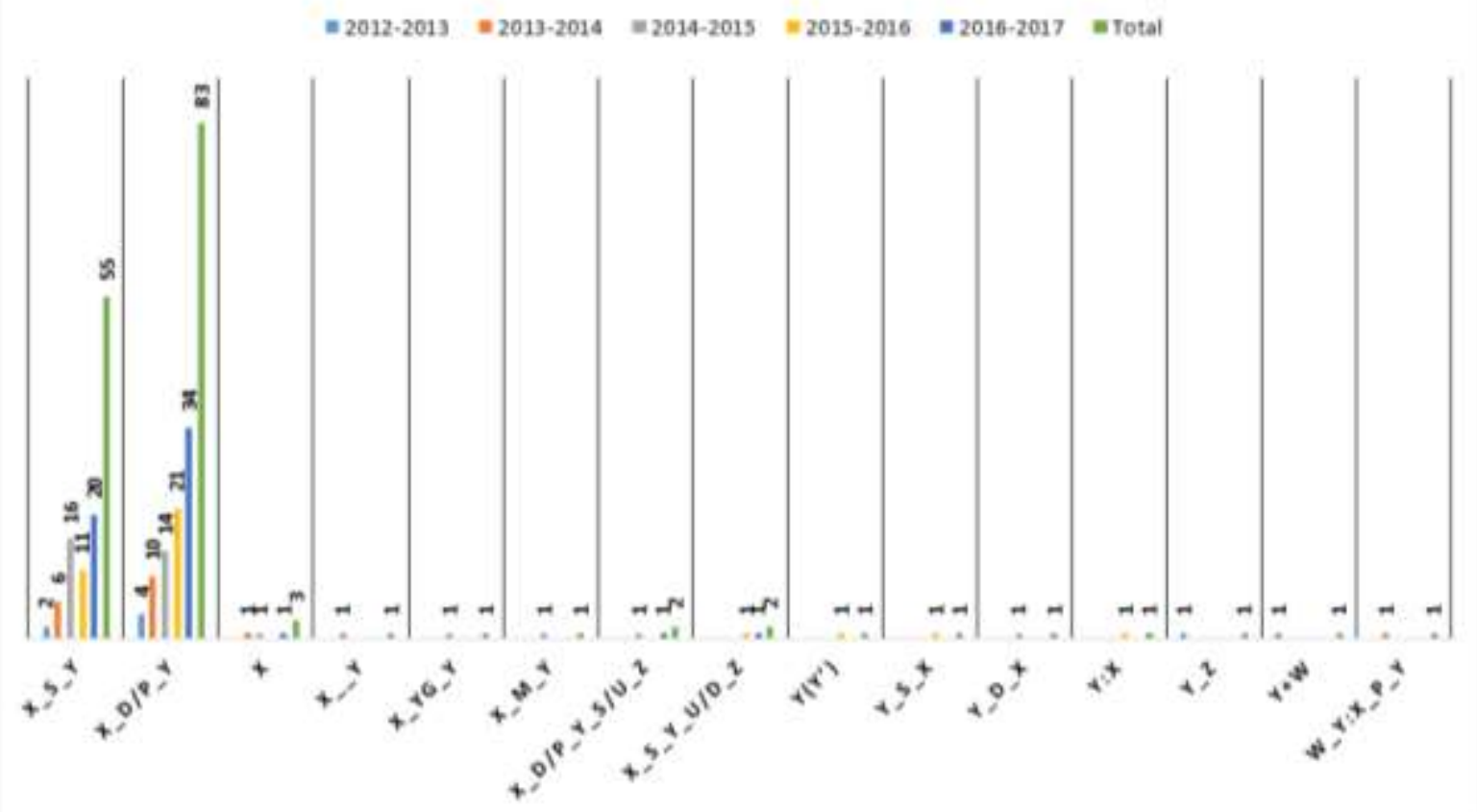

Grafik 1. Rumus Gaya Penyusunan Judul TA Penciptaan Mahasiswa Kriya, ISI Yogyakarta

Dari tabel 3 di atas dapat dilihat variasi gaya penyusunan judul TA Penciptaan mahasiswa Kriya, ISI Yogyakarta dari tahun 2012-2013. Penggambaran hasil rumus gaya penyusunan diperjelas dengan tampilan grafik 1 di atas yang menunjukkan bahwa rentang tahun 2012-2017 gaya judul berumus X_s_Y dan $\mathbf{X} \mathbf{d} / \mathbf{p} \mathbf{p} \mathbf{Y}$ mendominasi gaya judul TA.

\section{Menentukan Penonjolan Aspek dari Gaya Penyusunan Judul TA}

Rumus penggayaan judul TA yang berjumlah 15 variasi dalam rentang waktu 2012-2015 ini didominasi oleh 2 jenis rumus, yakni X_s_Y berjumlah 55 judul dan $X \_d / p \_Y$ berjumlah 83 judul. Teryata dugaan awal, gaya judul yang mendominasi ialah $X \_s \_Y$ 
atau "X sebagai Sumber Penciptaan Karya Y" meleset. Hasil analisis menunjukkan bahwa rumus X_d/p_Y atau "X dalam/pada Karya Y" berjumlah lebih banyak dibanding rumus X_s_Y. Keduanya bisa dikatakan sebagai gaya penyusunan judul yang paling banyak dipakai, bahkan terus mengalami peningkatan selama kurun waktu lima tahun ini. Oleh karena itu, dapat disimpulkan benar adanya bahwa juduljudul TA Penciptaan Mahasiswa Kriya, Fakultas Seni Rupa, ISI Yogyakarta masih "mengagung-agungkan" judul warisan atau judul latah yang bergaya $X \_d / p_{-} Y$ atau " $X$ dalam/pada Karya $Y$ " dan $X \_s \_Y$ atau " $X$ sebagai Sumber Penciptaan Karya $Y^{\prime \prime}$.

Salah satu contoh rumus penggayaan judul X_d/p_Y atau "X dalam/pada Karya Y": "Prajurit Keraton Yogyakarta dalam Busana Pesta Cocktail".

Prajurit Keraton Yogyakarta/ dalam Busana Pesta Cocktail

$\begin{array}{lll}\text { X (inti) } & \text { d }\end{array}$

Analisis di atas menunjukkan bahwa bagian inti dari frase prajurit keraton Yogyakarta dalam busana pesta cocktail diduduki oleh $\mathrm{X}=$ prajurit keraton Yogyakarta. Artinya bahwa dari gaya judul tersebut menonjolkan aspek $X$ sebagai bagian inti, yakni sumber penciptaannya, yaitu prajurit keraton Yogyakarta.

Salah satu contoh rumus penggayaan judul X_s_Y atau "X sebagai Sumber Penciptaan Karya $Y$ ": "Tokoh Petruk sebagai Sumber Ide Penciptaan Karya Seni Batik".

Tokoh Petruk/ sebagai Sumber Ide Penciptaan Karya Seni Batik $\mathrm{X}$ (inti) $\quad \mathrm{S} \quad \mathrm{Y}$ (atribut)

Analisis di atas menunjukkan bahwa bagian inti dari frase tokoh petruk sebagai sumber ide penciptaan karya seni batik diduduki oleh $\mathrm{X}=$ tokoh petruk. Artinya bahwa dari gaya judul tersebut menonjolkan aspek $X$ sebagai bagian inti, yakni sumber penciptaannya, yaitu tokoh petruk.

Jadi, dapatlah diambil simpulan bahwa dari kedua jenis gaya penyusunan judul TA yang secara signifikan sangat mendominasi selama lima tahun ini menonjolkan satu aspek, yakni aspek sumber penciptaan. Apakah betul memang hanya aspek sumber itulah yang ditonjolkan ataukah hanya karena ingin "aman" menggunakan judul warisan. Padahal jika mau lebih ekspresif dan eksploratif, masih banyak aspek yang bisa ditonjolkan jika melihat bagianbagian utama yang disampaikan dalam pedoman TA.

\section{Menonjolkan Aspek-Aspek Utama sebagai Dasar Penyusunan Judul TA Penciptaan}

Beberapa hal yang telah dipaparkan dalam bagian-bagian utama TA seharusnya bisa menjadi aspek yang ditonjolkan dan dirumuskan dalam judul TA. Seperti misalnya, sebenarnya karya TA terkadang diciptakan karena memiliki misi tertentu: sosialisasi, protes, kritik sosial, dan penginformasian isu terhangat. Misi tersebut seharusnya bisa ditonjolkan sebagai aspek dalam pembentukan judul TA. Dari kelima belas rumus gaya judul TA yang ditemukan, belum ada yang menonjolkan aspek misi dari karya seni, contohnya: "Mengenalkan Kembali Dolanan Tradisional melalui Karya Seni Keramik". Dari bagian utama TA, yakni Pendahuluan, selain sisi misi bisa juga menonjolkan sisi fungsi, tujuan, atau manfaat dari karya seni. Penonjolan aspek fungsi ditemukan dari salah satu rumus temuan, yakni Y_Z : "Eksotisme Keramik sebagai Aksesoris". $\mathbf{Z}$ menunujukkn aspek fungsi karya seni.

Bagian utama yang kedua dari TA ialah Konsep Penciptaan. Bagian ini terdiri atas Sumber Penciptaan dan Teori 
Penciptaan. Sumber penciptaan merupakan aspek dominan yang ditonjolkan, sedangkan Teori Penciptaan pun sebenarnya bisa menjadi aspek penting dalam penciptaan karya seni, sebagai contoh: "Deformasi Kendaraan Militer Tank dalam Karya Kriya Kayu".

Bagian utama yang ketiga ialah proses penciptaan, seperti bahan, alat, dan teknik bisa dijadikan sebagai aspek yang ditonjolkan. Bahan misalnya, bisa diangkat dalam judul jika memang karya seni memiliki nilai pembeda dilihat dari bahannya, sebagai contoh "Inovasi Jersey Batik untuk Pakaian Olahraga". Judul "Visualisasi Botol Keramik dengan Dekorasi Draperi" menonjolkan aspek teknik yang digunakan dalam pembuatan karya, yakni teknik draperi.

\section{PENUTUP}

Beberapa kegiatan yang telah dilaksanakan menghasilkan pengumpulan data judul sejumlah 160 judul dari tahun 2012-2017. Dari judul-judul tersebut telah dilakukan analisis berdasarkan atas satuan kebahasaan. Didapatkan hanya lima buah judul yang tidak memenuhi syarat sebagai judul karena berupa kalimat, sedangkan yang lain terpenuhi syarat berupa kata dan frase. Hal ini merupakan hasil bagus.

Data-data kemudian diklasifikasi dan dianalisis berdasarkan struktur frasenya, sehingga didapatkan pola frase yang cenderung dipilih mahasiswa. Hasilnya didapatkan sejumlah 15 variasi rumus gaya penyusunan judul TA selama kurun tahun 2012-2017. Dari variasi judul yang telah ditemukan ternyata ada 2 rumus gaya penyusunan judul yang mendominasi secara signifikan, yang salah satunya telah diduga di awal sebelum penelitian ini dilakukan, meskipun posisinya ada di peringkat kedua dilihat dari jumlahnya. Kedua rumus gaya penyusunan judul tersebut ialah $\mathbf{X} \mathbf{d} / \mathbf{p} \mathbf{p} \mathbf{Y}$ atau "X dalam/pada Karya $\mathbf{Y}$ " dan $\mathbf{X} \_$s_Y atau "X sebagai Sumber Penciptaan Karya Y". Dari struktur tersebut ditemukan fungsi inti dan atributnya, sehingga memudahkan untuk menemukan poin apa yang ditonjolkan dalam pembentukan judul, dilihat dari bagian-bagian utama yang ada dalam tugas akhir penciptaan mahasiswa Kriya. Ternyata dari kedua rumus judul TA yang mendominasi tersebut hanya ada satu aspek yang ditonjolkan, yakni $\mathrm{X}$, sumber penciptaan karya, meskipun dari 15 rumus gaya judul TA yang ditemukan ada beberapa aspek yang mulai dimunculkan seperti aspek W 'teknik' dan Z 'fungsi karya'.

Untuk menghasilkan variasi dalam gaya penyusunan judul TA harus dilakukan pembenahan pola pikir, bahwa penciptaan sebuah karya seni tidak hanya "melulu" menonjolkan sumber penciptaannya. Aspekaspek yang bisa ditonjolkan: misi, tujuan, manfaat, fungsi, sumber penciptaan, teori, bahan, alat, dan teknik. Seniman memiliki kebebasan berekspresi dalam menciptakan karya seninya, bahasa visual dari karya seni bisa dibahasa-lingualkan dalam gaya penyusunan judulnya.

\section{DAFTAR PUSTAKA}

Dewojati, Cahyaningrum. 2012. Panduan Penulisan Ilmiah dalam Bahasa Indonesia. Yogyakarta: Javakarsa Media.

Chaer, Abdul. 2007. Kajian Bahasa Struktur Internal, Pemakaian dan Pemelajaran. Jakarta: Rineka Cipta.

Djuroto, Totok dan Bambang Suprijadi. 2009. Menulis Artikel \& Karya Ilmiah. Bandung: Remaja Rosdakarya.

Indriati, Etty. 2003. Menulis Karya Ilmiah Artikel, Skripsi, Tesis, dan Disertasi. Jakarta: Gramedia Pustaka Utama.

"Pedoman Pembimbingan Tugas Akhir". Fakultas Seni Rupa Institut Seni Indonesia Yogyakarta 2016. 
Kesuma, Tri Mastoyo Jati. 2007. Pengantar (Metode) Penelitian Bahasa. Yogyakarta: Carasvatibooks.

Kridalaksana, Harimurti. 2002. Struktur, Kategori, dan Fungsi dalam Teori Sintaksis. Jakarta: Universitas Katolik Atmajaya.

Ramlan, M. 1996. Ilmu Bahasa Indonesia Sintaksis. Yogyakarta: CV. Karyono.

Subroto, Edi. 2007. Pengantar Metode Penelitian Linguistik Struktural. Surakarta: Lembaga Pengembangan Pendidikan UNS dan UPT Penerbitan dan Pencetakan UNS (UNS Press). 